\title{
Promoting African indigenous vegetables and its medical nutrition properties: A mini-narrative review based on Ukwani communities of Delta State Nigeria
}

\author{
Ishiekwene $\mathrm{IC}^{1}$, Dada $\mathrm{TE}^{2}$, OdokoJ ${ }^{3,4}$ and Nwose $\mathrm{EU}^{3,5 *}$ \\ ${ }^{1}$ Friends Laboratory, Obiaruku, Delta State Nigeria \\ ${ }^{2}$ School of Agriculture and Wine Science, Charles Sturt University Orange NSW Australia \\ ${ }^{3}$ Department of Public and Community Health, Novena University, Delta State Nigeria \\ ${ }^{4}$ Department of Community Health, Bayelsa State College of Technology, Otuogidi-Ogbia Nigeria \\ ${ }^{5}$ School of Community Health, Charles Sturt University Orange NSW Australia
}

\begin{abstract}
So much have been written on leafy vegetables including the African indigenous varieties, but optimum consumption is yet to be achieved. In the previous papers on food choices, it was recommended that some indigenous foods need to be incorporated as alternatives into food menu plans for the intended local population. This paper provides a narrative mini-review of the literature on some leafy vegetables consumed in Nigeria. Edible vegetable leaves such as water leaf (Talinum triangulare), fluted pumpkin (Telfairia occidentalis hook f.), bitter leaf (Vernonia amygdalina), Moringa oleifera, mint leaf, lemon grass, Amaranthus hybridus are cheap source of macro and micro nutrients including fibres, minerals, and vitamins amongst others. Yet, less than half of these indigenous vegetables are appreciated and commonly consumed. They have medicinal properties ability to act as a natural source of therapeutic agents. For instance, food fibres are now getting increased attention for their impact on health such as diabetes and cholesterol management. However, the indigenous vegetables that contribute to rural and urban people's diets in Nigeria, especially Ndokwa communities of Delta, have yet to be catalogued in a referenceable format. The aim is to catalogue the local names and production practice as a supplementary to the previous paper on food choices, especially because these selected indigeonus vegetable crops still need to be promoted for their contribution to healthy dietary habit. The nutritional values and traditional medicine usage forms are also briefly highlighted.
\end{abstract}

\section{Introduction}

Vegetable is often referred to as leafy or soft edible fruits which may be cooked in stew or eaten raw as a salad in Sub-Saharan Africa [1]. Some of these edible portions may be leafy for example bitter leaf, water leaf, fluted pumpkin, Moringa oleifera, mint leaf, lemmon grass, Amaranthus hybridus. African leafy vegetables help to meet the daily requirements of nutrients. The population of the rural region of subSaharan Africa identified as necessarily needing to increase vegetables in their diet [2]. Vegetables play an important role in human diet and nutrition as they contain both macro and micro nutrients including food fibres, various vitamins such as A, C and $\mathrm{K}$; as well as minerals such as iron, potassium, and zinc to human health development [3-6].

Leaf vegetables are affordable and quick to cook; rich in several nutrients particularly vitamin $\mathrm{C}$ and $\mathrm{B}$ - carotene, which is essential for human health. Consumption of vegetables in daily diet has been strongly associated with stress management and reduction in risk for the major diseases $[4,6]$. For instance, potassium-rich vegetables can reduce blood pressure [7-9], it is therefore imperative to advance this knowledge.

The wide range of leafy vegetables is consumed differently among households and this is influenced by various factors [10]. It is arguable that leafy vegetables alone have the potential to maintain optimum health status. However, traditional vegetables have the potential to contribute to the reduction of malnutrition among the rural region population by supplementing the diet and food diversification which are readily available in the field [11]. The intake of these indigenous vegetables in sub-Saharan Africa has been suboptimal relative to recommended dietary allowance (RDA) $[2,12,13]$. Hence, the need for research to advance the discourse and knowledge of indigenous leafy vegetables.

\section{Water leaf (Talinum triangulare)}

\section{Local names and production practices}

Talinum triangulare belongs to the family of Portulacaceae, is a short-lived perennial succulent shrub, which are sensitive to cold conditions. In Nigeria, the local name is bologi, which is pronounced 'gbologi', in Ukwani dialect of Delta state. It can grow wild on its own without cultivation (Figure 1).

\section{Nutritional values}

Talinum triangulare is known for its flavour, softness and taste. It is rich in fibre, protein and has various vitamins necessary for human

${ }^{\star}$ Correspondence to: Uba Nwose, School of Community Health, Charles Sturt University Orange NSW Australia, E-mail: enwose@csu.edu.au

Key words: African edible leaves, health benefits, indigenous vegetables, nutritional values

Received: May 13, 2019; Accepted: June 03, 2019; Published: June 06, 2019 


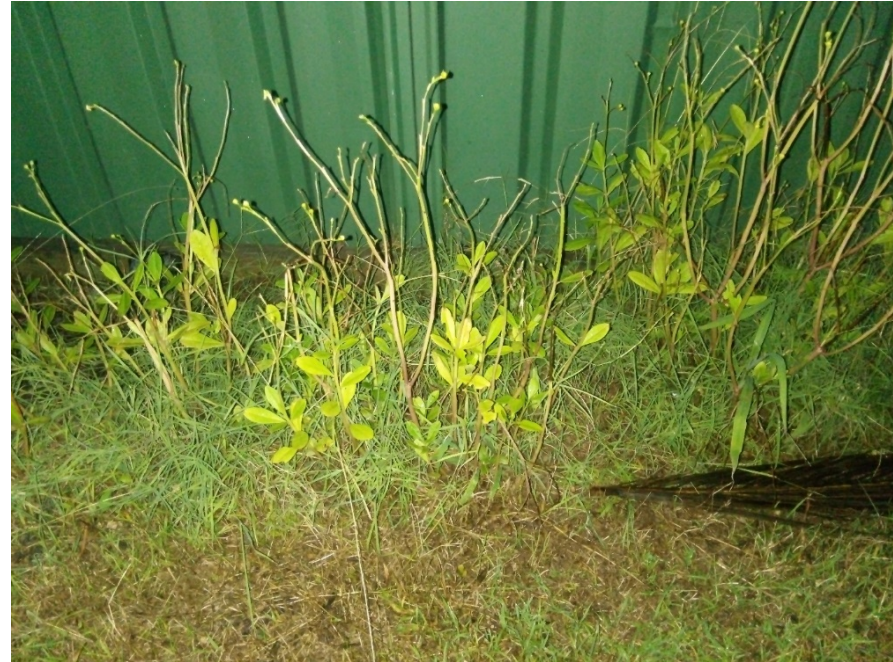

Figure 1. Water leaf plants in the backyard lawn

healthy diet [14]; and it is a good source of some important minerals such as magnesium and potassium; as well as antioxidant vitamins [15].

\section{Traditional medicine usage forms}

Waterleaf has proven to have a very strong amount of antioxidant, antimicrobial, and anti-inflammatory properties [15]. There is also the potentials for management of metabolic syndrome including diabetes, high cholesterol and hypertension [16-19]. In Nigeria soup made from waterleaf is eaten as a remedy for hypertension [14], which can be attributed to its high content of potassium [15].

\section{Consumption}

This vegetable is very appreciated and commonly consumed.

\section{Fluted pumpkin (Telfairia occidentalis)}

\section{Local names and production practice}

Fluted pumpkin is known in Nigeria as eweroko (Yoruba), ikongubong (Efik/Ibibio), ugu (Igbo) and offi (Ukwani). It is also known by different local names in other parts of Africa such as pondokoko or Gonugbe (Sierra Leone) and krobonko (Ghana); T. occidentalis is mostly cultivated in West Africa [20]. This vegetable crop is a perennial plant in the family of Cucurbitaceae widely cultivated for its nutritious and palatable leaves; and it is commonly grown as outdoor domestic food plant.

\section{Nutritional values}

Vegetables are known for their antioxidant properties as well as phenolic compounds; and Toccidentalis is no exception [21,22]. The leaves of fluted pumpkin has nutritive value (Figure 2), especially rich in minerals such as $\mathrm{Ca}, \mathrm{P}, \mathrm{Fe}$ contents being of higher percentage relative to other commonly used leafy vegetables $[20,23]$. While it may not be a reliable source of protein, the fibre content is quite moderate and the nutrient value underpins it usage forms [24].

\section{Medical uses}

Consumption of fluted pumpkin has the potential to protect human being from oxidative stress and its attendant health implications [20]. Based on mineral contents, the very high level of potassium in pumpkin leaf is speculated to possibly mitigate hypertensive [8,9]. Further, high iron content perhaps contributes to boosting blood production and can be used to treat anaemia. Also, the zinc content adds to the antioxidant potential [25], which may be benefical to e.g. diabetes management [1719,26].

\section{Consumption}

This vegetable is very appreciated and commonly consumed.

\section{Bitter leaf (Vernonia amygdalina)}

\section{Local names and production practices}

Bitterleaf plant is domestically grown almost universally, especially in the African tropical areas such as Nigeria. It is a shrub or small tree that can regenerate naturally (Figure 3). They grow well under full humid and sunlight environmental conditions. It is normally found along lakes and rivers, wood land, forest margins, and open grass land in the wild or it is cultivated [27]. The various local names in Nigeria

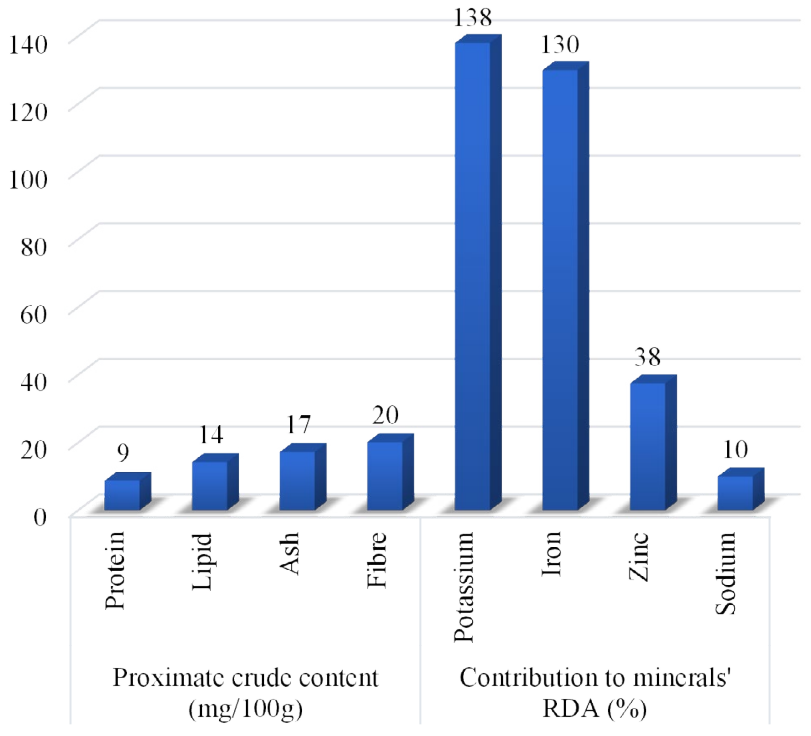

Figure 2. Some nutritional values and of fluted pumpkin leaf

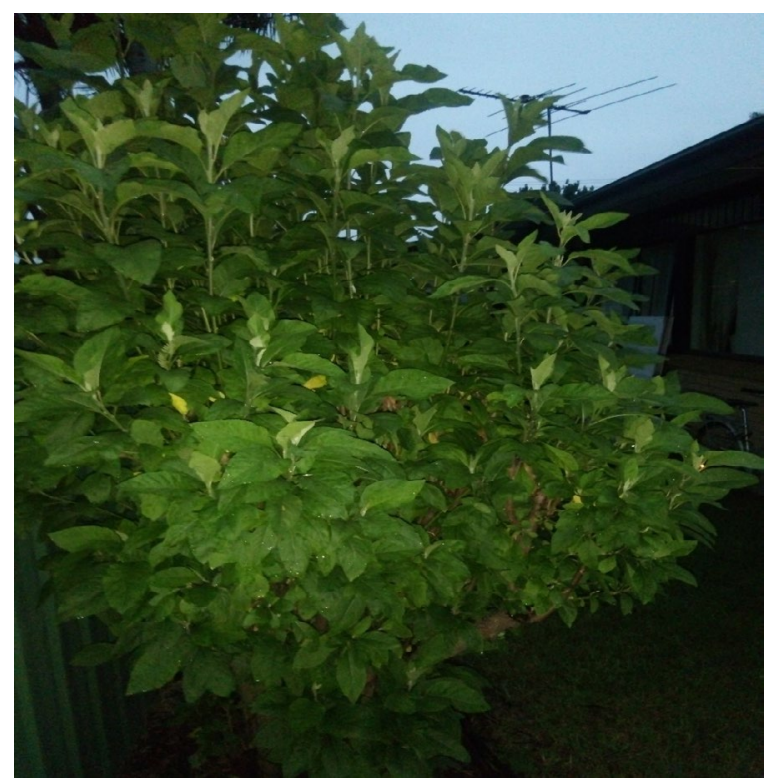

Figure 3. Bitter leaf tree in the backyard 
Ishiekwene IC (2019) Promoting African indigenous vegetables and its medical nutrition properties: A mini-narrative review based on Ukwani communities of Delta State Nigeria

include etidot (Efik/Ibibio), onugbu (Igbo and Ukwani), and Ewuro (Yoruba).

\section{Nutritional usage and values}

$V$. amygdalina leaves are used in Nigeria as spices in the very famous bitter-leaf soup. Extracts are rich in various phenolic and phytochemical compounds [28]. A recent report indicates that the nutritional values are comparable to mint leaf [29] - described next in the text. It has been reported to be exceptionally richest in folic acids and vitamin $\mathrm{C}$ relative to all other vegetables [2].

\section{Traditional/medical uses}

V. amygdalina is used in traditional herbal medicine. The versatile traditional uses of this vegetable is known to include alleviating malnutrition that may be due to micronutrient deficiencies [2]. It is also reported to be useful in the treatments for diabetes [26,30-32] and lowers cholesterol [33], as well as useful in treatment of infections [28].

\section{Consumption}

This vegetable is very appreciated and commonly consumed.

\section{Mint leaf (Ocimum gratissimum)}

\section{Local names and production practices}

Mint leaf (Ocimum gratissimum) called scent leaf is locally known in Nigeria as efinrin nla (Yoruba), alulu-nta (Ukwani) and dadoya (Hausa). It is cultivated in domestic vegetable gardens and has capacity to regenerate (Figure 4), as well as grow wildly.

\section{Nutritional values}

Mint leaf has a high amount of antioxidant, helps to add flavour when cooking and also involve in cutting down of sodium intake. In terms of proximate composition of nutritional contents, mint is comparable to bitter leaf [29]. It is commonly used in tea and is a spice in African cuisines.

\section{Traditional/medicine uses}

Mint leaf is traditionally associated with aromatherapy due to menthol and mint essential oil [34]. It has been used to manage several diseases including cold, cough, and asthma [35]. It is reported to be potentially for anticancer [36,37], and it is used in diabetes treatment [38].

\section{Consumption}

This vegetable is appreciated, but not commonly consumed.

\section{Green amaranth (Amaranthus hybridus)}

\section{Local names and production practices}

Amaranthus hybridus (green tete or morogo) is locally known in Nigeria as tete (Yoruba), alaiyaho (Hausa), inine (Igbo) and shorokotom yokotor (Ukwani). It grows wild in the farms, but can also be cultivated.

\section{Nutritional values}

Amaranthus is highly nutritious, both the grain amaranth and the leaves are utilized for human and animal food. In a study that compared the proximate composition of ten vegetables in Southern Nigeria, the amaranth was reported to be the healthiest in fat content; whilst being comparable to bitterleaf, mintleaf and waterleaf in fibres [39]. A. hybridus has great potential for allevating micronutrient malnutrition, due to its iron and antioxidant properties (Table 1) [40]. In the farms of the Ndokwa communities of Delta State Nigeria, this leafy vegetable is naturally growing, thus a free source of micronutrient food.

\section{Traditional medicine usage forms}

Table 1 shows the micronutrient composition of $A$. hybridus leaf. It is noteworthy that the zinc plays a role in fertility and its potential for diabetes management has been reported [41].

\section{Consumption}

This vegetable is appreciated, but not commonly consumed.

\section{Moringa oleifera}

\section{Local names and production practices}

Moringa oleifera belongs to Moringaceae and is commonly referred to as miracle tree, horseradish [42] or drumstick tree grown as a medicinal and food source. In Nigeria, it is famously called okwe or okwe-oyibo in Igbo and Ukwani. It grows wildly as a tree at both farming and living areas, though almost extinguished in the latter (Figure 5).

\section{Nutritional values}

M. oleifera is rated as high valued food source to promote good health and also act as traditional treatment for various diseases [43]. The leaves of the plant can be cooked, powdered or used raw and still preserve its nutritional value. Moringa oleifera leaves have been reported to contain more vitamin $\mathrm{C}$ than lemon and orange [44]. These leaves are rich in bioactive compounds including antioxidants [43].

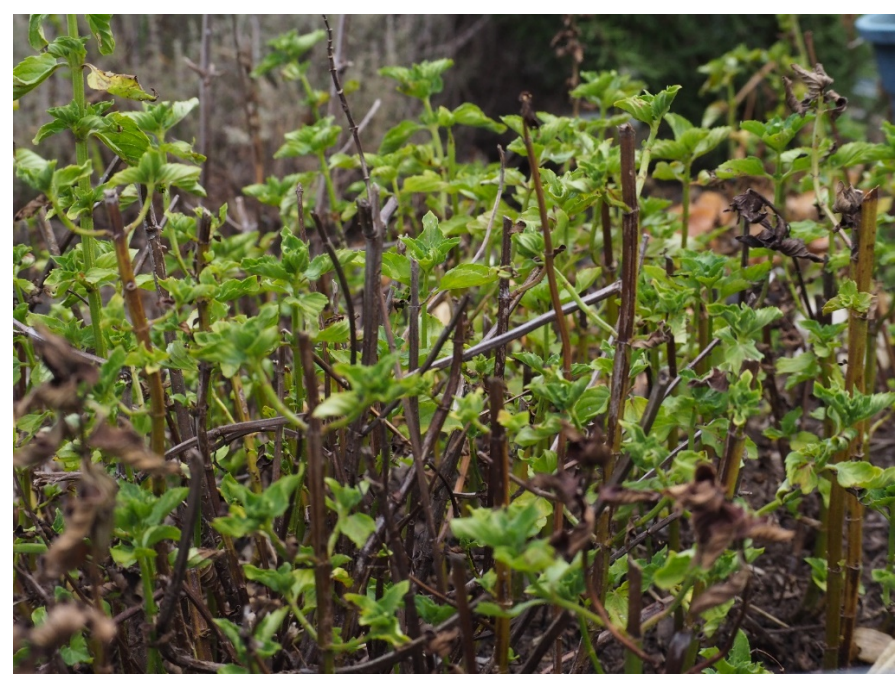

Figure 4. Mint leaf garden patch in apparently regenerating state

Table 1. Some micronutrient composition of A. hybridus leaf

\begin{tabular}{|c|c|c|}
\hline & Micronutrient & Composition \\
\hline \multirow{2}{*}{$\begin{array}{c}\text { Minerals } \\
(\mathrm{ppm})\end{array}$} & Iron & 150 \\
\cline { 2 - 3 } & Manganese & 75 \\
\cline { 2 - 3 } & Zinc & 54 \\
\hline \multirow{2}{*}{$\begin{array}{l}\text { Vitamins } \\
(\mathrm{ug} / \mathrm{mL})\end{array}$} & A (B-carotene) & 107 \\
\cline { 2 - 3 } & B2 (riboflavin) & 31 \\
\hline & C (ascorbate) & 4487 \\
\hline
\end{tabular}




\section{Medical values}

Moringa oleifera leaf has been investigated as alternative therapeutic agent in several diseases including stress, infection and diabetes $[45,46]$; as well as high cholesterol, hypertension, liver problems and wound management [42,43,47-49]. Interestingly, its usage for managmenet of these health conditions is only beginning to gain acceptance [46], which makes this narrative review imperative to advance the knowledge.

\section{Consumption} State.

This vegetable is not appreciated and hardly consumed in Delta

\section{Lemon grass (Cymbopogon citratus)}

Lemon grass is a native plant in the family Poaceae, also known as non-native plants. In Ukwani community of Delta State Nigeria, it is called atta-okuku and atta-oyibo and used to cook chicken culinary. It grows naturally, but also cultivated e.g. as a cash-crop in other countries.

\section{Nutritional values}

The nutritional values of lemon grass are comparable with pumpkin leaf (Figure 6) and chives (Figure 7). In particular, lemon grass is indicated to contain about fourteen times the amount of manganese in chives [50]. Indeed, lemon grass is used in tea as herbal infusion $[7,50,51]$.

\section{Traditional medicine usage forms}

Lemon grass grass has long been used in traditional medicine for treatment of several diseases including diabetes and high cholesterol [52,53]. The medicinal usefulness of lemongrass has recently been reviewed [54]. What is added in this narrative is a brief indication of its fibre values in terms of carbohydrate/fibre and fat/fibre ratios. For instance, there is evidence from literature that the fat/fibre ratio of lemon grass may be healthier relative to pumpkin leaf (Figure 6). Therefore, considering spicy delicacy for an individual controlling cholesterol and weight management, lemon grass is serving this purpose.

\section{Consumption}

This vegetable is appreciated, but not commonly consumed.

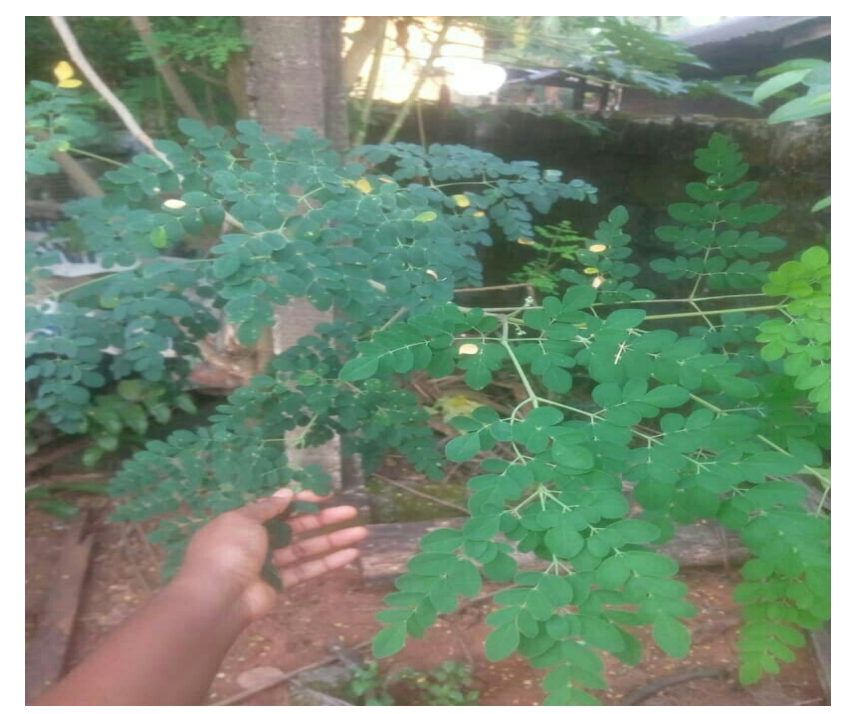

Figure 5. Moringa oleifera tree

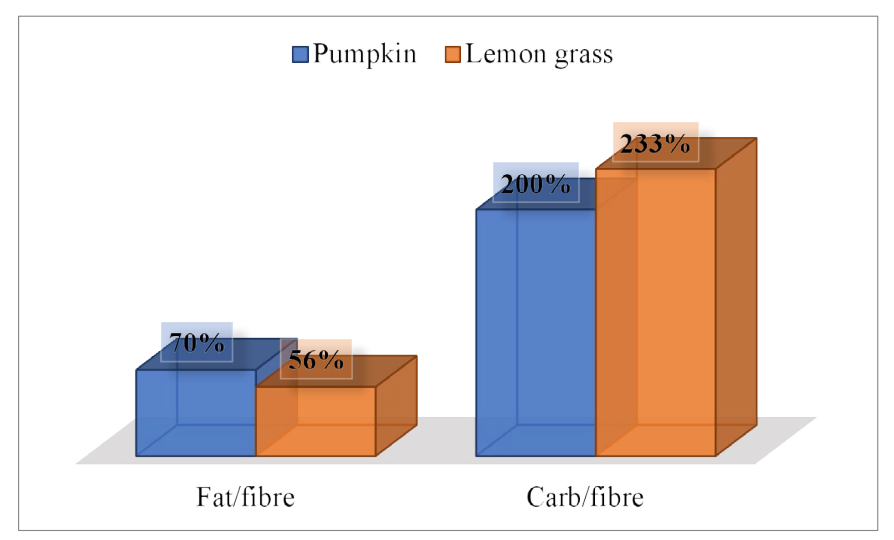

Figure 6. Food fibre values of lemon grass relative to pumpkin leaf $[7,51]$

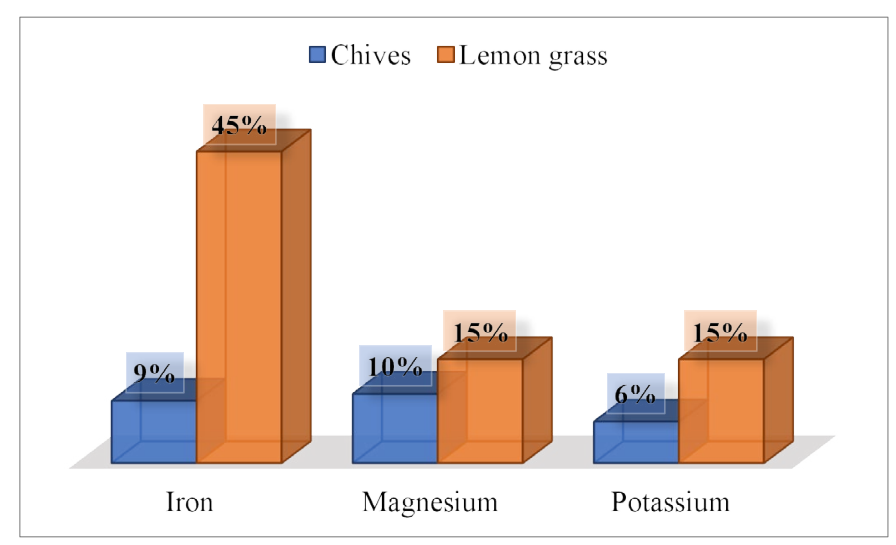

Figure 7. Some mineral contents' value of lemon grass relative to chives [50]

\section{Conclusion}

In Nigeria, as in most other tropical countries of Africa where the daily diet is dominated by starchy staple foods, vegetables are the cheapest and most readily available sources of micronutrients. Many of the local vegetable materials are under-exploited because of inadequate knowledge of their nutritional values regarding health benefits. This minireview provides seven of such indigenous leafy vegetables. Only three of them $(<50 \%)$ are well appreciated and commonly consumed and one $(\approx 14 \%)$ is not appreciated or eaten in our research performance community. There are still others like usually eaten by the Ukwani people that are now apparently forgotten, which would be covered later.

\section{Acknowledgement}

IIC is a botanist and his affiliated pathology laboratory is an institutional support base of NEU's diabetes research. DTE has participated in this review work as preliminary to her $\mathrm{PhD}$ work, while JO hopes to scale up the diabetes work. Pictures of leafy vegetables presented in this manuscript are original photos produced by IIC and NEU. Authors are grateful to Dr Phillip Bwititi for helping to review the manuscript.

\section{References}

1. Nyathi MK, Mabhaudhi T, Van Halsema GE, Annandale JG, Struik PC (2019) Benchmarking nutritional water productivity of twenty vegetables - A review. Agric Water Manage 221: 248-259.

2. Uusiku NP, Oelofse A, Duodu KG, Bester MJ, Faber M (2010) Nutritional value of leafy vegetables of sub-Saharan Africa and their potential contribution to human health: A review. Journal of Food Composition and Analysis 23: 499-509. 
3. Polidori MC, Carrillo JC, Verde PC, Sies H, Siegrist J, et al. (2009) Plasma micronutrient status is improved after a 3-month dietary intervention with 5 daily portions of fruits and vegetables: implications for optimal antioxidant levels. Nutr $J$ 8: 10. [Crossref]

4. Tsumbu CN, Deby-Dupont G, Tits M, Angenot L, Franck T, et al. (2011) Antioxidant and antiradical activities of Manihot esculenta Crantz (Euphorbiaceae) leaves and other selected tropical green vegetables investigated on lipoperoxidation and phorbol-12myristate-13-acetate (PMA) activated monocytes. Nutrients 3: 818-838. [Crossref]

5. Andarwulan N, Batari R, Sandrasari DA, Bolling B, Wijaya H (2010) Flavonoid content and antioxidant activity of vegetables from Indonesia. Food Chem 121: 12311235. [Crossref]

6. Harsha C, Banik K, Bordoloi D, Kunnumakkara AB (2017) Antiulcer properties of fruits and vegetables: A mechanism based perspective. Food Chem Toxicol 108: 104119. [Crossref]

7. Idris S (2011) Compositional studies of Telfairia Occidentalis leaves. Am J Chem 1: 56-59.

8. McDonough AA, Nguyen MTX (2012) How does potassium supplementation lower blood pressure? Am J Physiol Renal Physiol 302: F1224-F1225. [Crossref]

9. Veiras LC, Han J, Ralph DL, McDonough AA (2016) Potassium supplementation prevents sodium chloride cotransporter stimulation during angiotensin II hypertension. Hypertension 68: 904-912. [Crossref]

10. Gido EO, Ayuya OI, Owuor G, Bokelmann W (2017) Consumer Acceptance of leafy African indigenous vegetables: comparison between rural and urban dwellers. International Journal of Vegetable Science 23: 346-361.

11. Medoua GN, Oldewage-Theron WH (2014) Effect of drying and cooking on nutritional value and antioxidant capacity of morogo (Amaranthus hybridus) a traditional leafy vegetable grown in South Africa. J Food Sci Technol 51: 736-742. [Crossref]

12. Nwose EU, Onokade M, Agofure O, Johnson E, Igumbor EO (2019) Diabetes peereducation on food choices part II: Adoptability of menu plans in low-mid income communities. Integr Food Nutr Metab 6.

13. Oguoma VM, Nwose EU, Skinner TC, Richards RS, Bwititi PT (2018) Diet and lifestyle habits: Association with cardiovascular disease indices in a Nigerian subpopulation. Diabetes Metab Syndr 12: 653-659. [Crossref]

14. Aja PM, Okaka ANC, Ibiam UA (2010) Proximate analysis of Talinum triangulare (Water Leaf) leaves and its softening principle. Pakistan Journal of Nutrition 9: 524526.

15. Ikewuchi CC, Ikewuchi JC, Ifeanacho MO (2016) Bioactive phytochemicals in an aqueous extract of the leaves of Talinum triangulare. Food Sci Nutr 5: 696-701. [Crossref]

16. Olorunnisola OS, Adetutu A, Afolayan AJ, Owoade AO (2016) Effect of methanolic leaf extract of Talinum triangulare (Jacq). Willd on biochemical parameters in diet induced Dyslipidemia Wistar rats. Pharmacogn Mag 12: 333-339. [Crossref]

17. Teugwa CM, Boudjeko T, Tchinda BT, Pascaline CM, Denis Z (2013) Antihyperglycaemic globulins from selected Cucurbitaceae seeds used as antidiabetic medicinal plants in Africa. BMC Complement Altern Med 13: 63.

18. Xu W, Zhou Q, Yin JJ, Yao Y, Zhang JL (2015) Anti-diabetic effects of polysaccharides from Talinum triangulare in streptozotocin (STZ)-induced type 2 diabetic male mice. Int J Biol Macromol 72: 575-579. [Crossref]

19. Ijomone OR, Ekpe EL (2016) Antidiabetic potentials of common herbal plants and plant products: A glance. International Journal of Herbal Medicine 4: 90-97.

20. Eseyin OA, Sattar MA, Rathore HA (2014) A Review of the pharmacological and biological activities of the aerial parts of Telfairia occidentalis Hook $\mathrm{f}$ (Cucurbitaceae). Tropical Journal of Pharmaceutical Research 13: 1761-1769.

21. Oboh G, Nwanna E, Elusiyan C (2010) Antioxidant and antimicrobial properties of Telfairia occidentalis (Fluted pumpkin) leaf extracts. Journal of Pharmacology \& Toxicology 5: 539-547.

22. Jalali Ghassam B, Ghaffari H, Prakash HS, Kini KR (2014) Antioxidant and hepatoprotective effects of Solanum xanthocarpum leaf extracts against CC14-induced liver injury in rats. Pharm Biol 52: 1060-1068. [Crossref]

23. van Jaarsveld P, Faber M, van Heerden I, Wenhold F, van Rensburg WJ, et al. (2014) Nutrient content of eight African leafy vegetables and their potential contribution to dietary reference intakes. Journal of Food Composition and Analysis 33: 77-84.

24. Aworunse O, Bello O, Popoola J, Obembe O (2018) Pharmacotherapeutic properties of Telfairia occidentalis Hook F.: A systematic review. Pharmacognosy Reviews 12: 238-249.
25. Goddard AF, James MW, McIntyre AS, Scott BB, British Society of Gastroenterology (2011) Guidelines for the management of iron deficiency anaemia. Gut 60: 1309-1316. [Crossref]

26. Ssenyange CW, Namulindwa A, Oyik B, Ssebuliba J (2015) Plants used to manage type II diabetes mellitus in selected districts of central Uganda. Afr Health Sci 15: 496-502. [Crossref]

27. Cock IE, Selesho MI, Van Vuuren SF (2018) A review of the traditional use of southern African medicinal plants for the treatment of selected parasite infections affecting humans. J Ethnopharmacol 220: 250-264. [Crossref]

28. Farombi EO, Owoeye O (2011) Antioxidative and chemopreventive properties of Vernonia amygdalina and Garcinia biflavonoid. Int J Environ Res Public Health 8: 2533-2555. [Crossref]

29. Okunlola GO, Jimoh MA, Olatunji OA, Rufai AB, Omidiran AO (2019) Proximate analysis, mineral composition, and antioxidant properties of bitter leaf and scent leaf. International Journal of Vegetable Science 25: 346-354.

30. Asante DB, Effah-Yeboah E, Barnes P, Abban HA, Ameyaw EO, et al. (2016) Antidiabetic effect of young and old ethanolic leaf extracts of Vernonia amygdalina: A comparative study. J Diabetes Res 2016: 8252741. [Crossref]

31. Atangwho IJ, Yin KB, Umar MI, Ahmad M, Asmawi MZ (2014) Vernonia amygdalina simultaneously suppresses gluconeogenesis and potentiates glucose oxidation via the pentose phosphate pathway in streptozotocin-induced diabetic rats. BMC Complement Altern Med 14: 426. [Crossref]

32. Michael UA, David BU, Theophine CO, Philip FU, Ogochukwu AM, et al. (2010) Antidiabetic effect of combined aqueous leaf extract of vernonia amygdalina and metformin in rats. J Basic Clin Pharm 1: 197-202. [Crossref]

33. Adaramoye OA, Akintayo O, Achem J, Fafunso MA (2008) Lipid-lowering effects of methanolic extract of Vernonia amygdalina leaves in rats fed on high cholesterol diet. Vasc Health Risk Manag 4: 235-241. [Crossref]

34. Antora RA, Salleh RM (2017) Antihyperglycemic effect of Ocimum plants: A short review. Asian Pac Trop Biomed 7: 755-759.

35. Jamila F, Mostafa E (2014) Ethnobotanical survey of medicinal plants used by people in Oriental Morocco to manage various ailments. J Ethnopharmacol 154: 76-87. [Crossref]

36. Jain D, Pathak N, Khan S, Raghuram GV, Bhargava A, et al. (2011) Evaluation of cytotoxicity and anticarcinogenic potential of Mentha leaf extracts. Int J Toxicol 30: 225-236. [Crossref]

37. Hussain AI, Anwar F, Nigam PS, Ashraf M, Gilani AH (2010) Seasonal variation in content, chemical composition and antimicrobial and cytotoxic activities of essential oils from four Mentha species. J Sci Food Agric 90: 1827-1836. [Crossref]

38. Abdellatief SA, Beheiry RR, El-Mandrawy SAM (2017) Peppermint essential oil alleviates hyperglycemia caused by streptozotocin- nicotinamide-induced type 2 diabetes in rats. Biomed Pharmacother 95: 990-999. [Crossref]

39. Akinwunmi OA, Omotayo FO (2016) Proximate analysis and nutritive values of ten common vegetables in South-West (Yoruba land) Nigeria. Communications in Applied Sciences 4: 79-91.

40. Adewale A, Olorunju AE (2013) Modulatory of effect of fresh Amaranthus caudatus and Amaranthus hybridus aqueous leaf extracts on detoxify enzymes and micronuclei formation after exposure to sodium arsenite. Pharmacognosy Res 5: 300-305. [Crossref]

41. Balasubramanian T, Karthikeyan M, Muhammed Anees KP, Kadeeja CP, Jaseela K (2017) Antidiabetic and antioxidant potentials of Amaranthus hybridus in Streptozotocin-induced diabetic rats. J Diet Suppl 14: 395-410. [Crossref]

42. Ravani A, Prasad RV, Gajera RR, Joshi DC (2017) Potentiality of Moringa oleifera for food and nutritional security - a review. Agric Rev 38: 228-232.

43. Vergara-Jimenez M, Almatrafi MM, Fernandez ML (2017) Bioactive components in Moringa oleifera leaves protect against chronic disease. Antioxidants (Basel) 6 [Crossref]

44. Mbailao M, Mianpereum T, Albert N (2014) Proximal and elemental composition of Moringa oleifera (Lam) leaves from three regions of Chad. Journal of Food Resource Science 3: 12-20.

45. Madi N, Dany M, Abdoun S, et al. (2016) Moringa oleifera's nutritious aqueous leaf extract has anticancerous effects by compromising mitochondrial viability in an ROSdependent manner. J Am Coll Nutr 35: 604-613. [Crossref]

46. Popoola JO, Obembe OO (2013) Local knowledge, use pattern and geographical distribution of Moringa oleifera Lam. (Moringaceae) in Nigeria. $J$ Ethnopharmacol 150: 682-691. [Crossref] 
Ishiekwene IC (2019) Promoting African indigenous vegetables and its medical nutrition properties: A mini-narrative review based on Ukwani communities of Delta State Nigeria

47. Helmy SA, Morsy NFS, Elaby SM, Ghaly MAA (2017) Hypolipidemic effect of Moringa oleifera Lam leaf powder and its extract in diet-induced hypercholesterolemic rats. JMed Food 20: 755-762. [Crossref]

48. Tiloke C, Anand K, Gengan RM, Chuturgoon AA (2018) Moringa oleifera and their phytonanoparticles: Potential antiproliferative agents against cancer. Biomed Pharmacother 108: 457-466. [Crossref]

49. Chin CY, Jalil J, Ng PY, Ng SF (2018) Development and formulation of Moringa oleifera standardised leaf extract film dressing for wound healing application. $J$ Ethnopharmacol 212: 188-199. [Crossref]

50. SkipThePie (2017) Nutritional info of: Lemon grass (citronella) raw vs. chives raw. Accessed $4^{\text {th }}$ July, 2019. https://skipthepie.org/vegetables-and-vegetable-products/ lemon-grass-citronella-raw/compared-to/chives-raw/
51. Thorat PP, Sawate AR, Patil BM, Kshirsagar RB (2017) Proximate and phytonutrient content of Cymbopogon citratus (Lemongrass) leaf extract and preparation of herba cookies. International Journal of Chemical Studies 5: 758-762.

52. Ekpenyong CE, Akpan E, Nyoh A (2015) Ethnopharmacology, phytochemistry, and biological activities of Cymbopogon citratus (DC.) Stapf extracts. Chin J Nat Med 13 321-337. [Crossref]

53. Adeneye AA, Agbaje EO (2007) Hypoglycemic and hypolipidemic effects of fresh leaf aqueous extract of Cymbopogon citratus Stapf. in rats. J Ethnopharmacol 112: 440444.

54. Haque ANMA, Remadevi R, Naebe M (2018) Lemongrass (Cymbopogon): A review on its structure, properties, applications and recent developments. Cellulose 25: 54555477.

Copyright: (C2019 Ishiekwene IC. This is an open-access article distributed under the terms of the Creative Commons Attribution License, which permits unrestricted use, distribution, and reproduction in any medium, provided the original author and source are credited. 